\title{
The Hey'ati Movement
}

\author{
Charismatic Preachers, Politics and Youth Culture
}

\author{
David Thurfjell
}

\section{1 Introduction}

This chapter explores the role of charismatic prayer leaders or eulogists, maddāhān, in the religious landscape of the Islamic Republic of Iran. A youth movement centred around these lay religious authorities has expanded during the last three decades. For instance, eulogists played a pivotal role in the mobilisation of popular support for former president Mahmoud Ahmadinejad. These charismatic leaders and the movement around them represent a form of Iranian folk religiosity that in connection to certain religious celebrations draws broad popular support. Lately it has also developed into a particular subculture with its own lifestyle, ritual repertoire and aesthetic expression.

In the following I will sketch the modern history of this movement based on the oral history of some of those who were a part of it. Having done this, I will analyse its place within the changing landscape of Islamic authority in Iran. Describing the movement as an expression of what I will call the amalgamation and aesthetics of authority I suggest that it may exemplify some ways in which religious authority is changing in our time. The movement around the maddāhān, it is argued, represents a renegotiation and a relocation of authority: not through the articulation of new jurisprudential or political positions, but through the reinterpretation of the ways in which people are letting religion become a part of their lives. The text is based on fieldwork and interviews conducted in Qom and Tehran from 2013 to $2016 .^{1}$

It is the first of the month of Sha'bān, ten o'clock in the evening, and the night is pleasantly hot in Qom. Tonight is the evening before the birthdays of Imām Husayn (in the Persian colloquial: Hoseyn) ibn 'Alī and his brother 'Abbas, both of whom were martyred in Karbalā'. To commemorate the occasion, one of the many local congregation halls (hoseyniehs) is organising an evening with religious talks and singing. Shabān is a joyous month in the Shīite calendar

1 For the sake of anonymisation, the dates and specific locations of the interviews will not be revealed. 
and the walls of the hoseynieh where we have gathered are carefully dressed in pink and green cloth. Plastic flowers are placed on the podium and most of the visitors are dressed in pale colours. The speaker of the evening is a scholar and a eulogist who has profiled himself as a demagogue on the conservative side of Iranian politics for some years, and lately he has built himself quite a reputation in hardliner circles. He is dressed all in white this evening with a white turban, a long, greying beard, and the traditional dress of a clergyman. His glasses are square-shaped and metal-framed, of the type the Supreme Leader himself wears and that was given out to the soldiers in the Iraqi war. Along with the folded Palestinian kefiyeh that he wears around his neck, the glasses evoke memories of that war. In today's Iran, these are recognisable signs of a hardliner position and declare an affinity to the sepāh or basij organisations.

This preacher is hostile to reformist clergy such as Ayatollah Montazeri (1922-2009) and Ayatollah Yousef Sancei (b. 1937). He is not happy with the way these two clerics were critical of the way the authorities dealt with the Green movement and the reformist demonstrations following the disputed presidential election of 2009. Following the funeral of Montazeri in the same year, he was involved in attacks on their offices and in calling for their defrocking. Although it is now more than five years since these events took place, the talk this night circles around the same theme. He is critical of the former president Mahmoud Khatami and his understanding of the notion of velāyat-e faqih. "Khatami and Montazeri wanted to limit the scope of the veläyat of the Supreme Leader [rahbar]," he explains, "but that was wrong. The authority of the Supreme Leader is wide and no one can change that." He then continues with what seems to be a threat of what may come if people mess with these principles. "Montazeri criticised the leader [valī] himself and not the whole notion of velāyat-e faqīh and for this he was attacked." The preacher here raises his index finger in affirmation, and then, reproachfully shaking his head, he continues solemnly, "had he criticised the notion as a whole, his punishment would have been much harsher." The topic of the speech then moves on to the fighting in Syria and a legal discussion about whether mercenaries who fight for Hizballāh in that conflict for the pay — rather than out of convictionshould still be considered martyrs if they are killed. The preacher declares that they should.

When the speech is over, he moves on to the singing of tonight's eulogy. He has the lyrics written on a piece of paper and sings the eulogy with a strong voice, leaning forward and gesturing as if to emphasise his eagerness to get the message across. The poem is on the theme of the night, Hoseyn's birth, andthis being Shīism - also about his tragic martyrdom. There is an undertone of violence to the content of both speech and eulogy, but the atmosphere in the 
room is anything but violent. The men gathered there listen with varying levels of attention. Some fiddle with their mobile phones. A few of them are drowsing, and there are a number of children running around and playing, despite their fathers' half-hearted cautioning. At the end of the session, the preacher rewards their endurance by smilingly picking up a bucket filled with sweets from under his chair and sprinkling its contents over the audience.

This preacher is a maddāh (literally 'eulogist'), and the group assembled in his hoseynieh is a hey'at (literally 'gathering', plural hey'atha a). These are institutions with a long history in the Shīite world. Over the last two decades, however, their role in Iranian society and politics has changed. The popular influence of the maddāhān has increased, and the widespread folk tradition of the hey'at has grown into what could be described as a subculture youth movement, a movement sometimes referred to as the new hey'ati and one with ambiguous connections to the ever-ongoing intrigues and negotiations of religio-political authority in Iran. Although the borders of this subculture remain indistinct, and although there are vast differences within it, hey'at communities have today developed into a subculture with institutions, information channels, ritual practices, leaders and aesthetic features that are distinct from other Islamic movements in the Islamic Republic.

\section{The Modern History of Hey'athā and Maddāhān}

The word hey'at is an Arabic loanword that literally means 'group' or 'delegation'. In a Persian religious context, the word signifies a group that gathers to mourn for Hoseyn and the other members of the household of the Prophet (ahl-e bayt). Hey'atī (plural hey'atīha $\overline{\text { ) }}$ is the adjective that signifies someone who belongs to such a group. Hey'at groups constitute a common feature in the popular Iranian religious landscape, and they have a long history. Traditionally, informal groups have formed on a neighbourhood basis to commemorate events in the Shīite calendar. Often the organisational responsibility has rotated between households. In connection to religious celebrations, they have organised sermons, Qurān classes or, most prominently, mournful lamentation sessions known as rouzeh or nuhe in people's private homes or in hoseyniehs. Individuals may also organise gatherings as a sign of gratitude for a prayer answered or recovery from illness. There is a traditional connection between the hey'athā and the $b \bar{a} z \bar{a} r i$ class, but groups have also been formed based on ethnicity, friendship or gender (Momen 1985: 238-240). Hey'at groups, furthermore, have also played a role in the organisation of ziyārat, that is, pilgrimage visits to the shrines of Mashhad and Qom as well as other 
religiously significant sites. Here the local hey'atha have organised the practical arrangements as well as the ritual content of these journeys (Fischer 1980: 134-135). In connection to the commemorative rituals of the first ten days of Muharram, the hey'atha have also played a pivotal role. And in the processions that fill the streets of most Iranian cities on the day of Ashura the most fervent chest-beaters who constitute the core groups often consist of hey'atīha . It is no exaggeration, therefore, to say, with Michael Fischer, that the hey'athā have traditionally provided the skeleton of popular religion in Iran (Fischer 1980: 135).

Every hey'at pivots around its maddāh. A maddāh (plural maddāhān, from Arabic madh, eulogy) is a eulogist or a performer of mourning prayers. A person given this task may in Persian also be referred to as a $z \bar{a} k e r$ (from Arabic dhākir, meaning commemorator) or a rouzeh khān (reader of rouzeh). Traditionally, maddāhān are not clergy. They do not wear a turban and they usually have no theological or jurisprudential education. They are typically lay people of other professions who are engaged because of their good singing voice, their knowledge of pious poetry, and their skills in evoking religious emotion. Usually they are called häjji or seyyed by their followers.

Non-clerical religious authorities have existed in Iran for a long time, and maddāhān have had a role in Iranian religious culture since Șafavid times (Mitchell 2011: 144). But before the Revolution their societal authority was confined to the festivals at which they said their prayers, and they constituted no threat or challenge to the monarchy or the jurisprudential authority of the 'ulam $\bar{a}$. During the Pahlavi era it was the tradition to end hey'at gatherings with prayers for the king. This practice was criticised by revolutionary pioneers such as Murtaza Mutahhari and 'Ali Shariati, who allegedly even quoted Karl Marx in describing the pro-monarchist hey'ath $\bar{a}$ as an opium of the people, offering quick-fix heavenly rewards without any demand for righteous engagement (Mazaheri 2008: 9).

After the Islamic Revolution of 1979, and in the chaos that endured during its first years, mourning rituals of various types flourished. The activities around local shrines increased dramatically as people gathered to listen to maddāhān, pray, and, not least, praise the Hidden Imam. Some entirely new traditions were even invented, like ten days of mourning in honour of Fatemeh Zahra (Amanat 2009: 226). According to the Iranian-British historian Abbas Amanat, it was in this apocalyptic and revolutionary environment that a new spirit of camaraderie emerged in connection to the hey'atī culture. According to him, it was especially among the young basijj and Revolutionary Guards that this new spirit evolved, and it was especially flavoured by the messianic awareness of the early days of the Revolution (Amanat 2009: 226). The maddāhān now proved to be resourceful also in mustering political engagement, and for 
this reason they have since become a force to count with in Iranian politics. Iranian anthropologist Mohsen Mazaheri, who has written the most extensive study on the modern history of the movement, categorises the hey'atha into five types: traditional, wartime revolutionary, post-war revolutionary, popular, and quasi (Mazaheri 2008). These categories differ in style but also in their age range, social base, and gender distribution.

The important position that the hey'atha have attained in today's Iran evolved in several steps. The early years of the Revolution and the impact of Ruhollah Khomeini (1902-1989) himself mark a first such step: the immediate post-revolutionary upsurge of hey'atī culture. Khomeini showed an appreciation for Shī' ite folk traditions by partaking in mourning rituals himself. He also had a maddāh, Hajj Seyyed Kowsari, who would follow him around and sing in traditional rouzeh khāni style for a few minutes at the end of the ayatollah's speeches. Khomeini, too, would weep at these sessions.

When Saddam Hussein invaded Iran on 22 September 1980 and the eightyear-long war with Iraq started, a formative period for the modern hey'ati movement began. In pro-revolutionary circles, the war became an opportunity to realise the self-sacrificial lifestyle that is celebrated in the Karbalä' commemorations. Perhaps it can be said that it was the ritual logic of revolutionary hey'atī culture that created the emotional regime that made thousands of young Iranian men volunteer to fight in the war. "All those volunteers," one of my hey'atī interviewees tell me, "came from this Hoseyn culture that tells you to give your blood for your honour, and you were so happy, and your family was so happy and proud" (interview with author, 2013). The clerical establishment that had risen to power in Iran used the maddāhān to stir the emotions needed to mobilise young men to enlist. Two particularly prominent maddāhān who rose to fame during this time were Sadeq Ahangaran and Gholam Koveyti Pour.

Since the ceasefire with Iraq in 1988, the war has continued to be an important reference for many hey'atī groups. Many hey'atīha were angry with President Rafsanjani and Mohsen Rezaie Mirqaed, chief commander of the sepāh (the Iranian Revolutionary Guard Corps), for not continuing the war. Some of them, one interviewee told me, even wrote a letter to Khomeini himself, offering their readiness to fight even if they had no weapons left to fight with. "Imam Hoseyn never gave up," they are supposed to have told him (interview with author, 2013). Today, romanticisation of the war is still an important element of the hey'ati lifestyle. The soldiers who fought and died in the war constitute a powerful image of the type of self-sacrificial lifestyle that the maddāhān promote. "It is the image of those martyred people," one former hey'atī tells me, 
their lifestyle, how they left everything, their studies, their money, women, everything to go to war. That became a utopian lifestyle for us that we wanted to imitate today in the cities also: the free, amazing, happy, spiritual way of life that they experienced in the war.

interview with author, 2014

Veterans from the war also played an important part in forming the hey'at $\bar{\imath}$ culture that developed in the period after the ceasefire. "In our group there were lots of people who survived the war and they were so influential," another interviewee tells me,

they missed the spiritual lifestyle that they had during the war. Now when they had come back life was so complicated. They needed to organise things and earn money and they could not be as spiritual as they had been in the war. They cried over this in the meetings and gave the young people [who had not been in the war] this sense that they missed that time.

interview with author, 2014

In the dramaturgical logic of the Karbalā' narrative, many hey'athā built up their post-war identity as a reflection of the tawwabūn (the Penitents). The tawwabūn were those who came too late to assist Hoseyn at Karbalä. Just as they were too late to help Hoseyn at Karbalā', some hey'atīhà today think of themselves as coming too late to fight for Islam in the Iraq war. One maddāh I interview tells me that he tries to convey this "feeling of being late" in his meetings because this feeling is particularly efficient in stirring the emotions of the crowd (interview with author, 2014).

Now the post-war era in Iran coincides with the succession from Khomeini to 'Ali Khamene'i. This change of leadership also entailed a professionalisation of the maddāhān. Khamene'i was not as unequivocally endorsed by the 'ulam $\bar{a}$ and their theological seminars as Khomeini had been. In order to secure his legitimacy, he sought support among groups in Iranian society that had been important in defending and supporting the revolutionary ideals during the time of the war. The maddāhann were one such group. The new leader endorsed this group, and some of them became important mouthpieces for him. A particularly important figure here is Hajj Mansour Arzi. He is probably the most influential political maddāh in modern Iranian history. Endorsed by Khamene'i in the first years of his leadership, Hajj Mansour Arzi profiled himself as a charismatic spokesperson of the hardliner camp in Iranian politics and a fervent supporter of the Supreme Leader. Hajj Mansour Arzi is based 
in Masjed-e Ark in Tehran and from there he has tightened up Iranian rouzeh culture and endeavoured to bring the stories told in the hey'atha more into line with officially sanctioned Shīism.

Hajj Mansour Arzi also brought about a change in ritual style. Under Khomeini, the endorsed eulogies of maddāhān like Kowsari had been short and traditional; under Khamene'i and maddāhān like Arzi, the ritual tradition found new expressions and expanded in influence. My interviewees tell me that much of this lay in the organisation. Arzi and his contemporaries were much more organised and professional in their approach to the whole thing. Kowsari was respected and knowledgeable, but he was not a professional singer or performer. "He sang some simple songs for five minutes and there would be some weeping," one interviewee tells me,

but Arzi, he would go on for more than an hour with perfect planning. First he would read a poem, then tell a story of Imam Zaman [i.e. the mahdī ] which would lead into an eulogy which would initiate some prechest-beating which in its turn led to loud chest-beating, hard weeping and a few minutes of shur [passionate style]. He was a masterful singer.

interview with author, 2014

Cassette recordings of Hajj Mansour Arzi's gatherings spread across the country, and his performances were sometimes broadcast on television. In this way his new style became a government-endorsed norm of hey'ati culture that came to be imitated in hoseyniehs across the country in the mid-199os (interview with author, 2013).

The rise of Hajj Mansour Arzi entailed an important change because it made hey'atī culture a part of the power play between rivalling camps in Iranian politics. This marked the next phase of the development of hey'atī culture in Iran, unfolding in the late 199os. From this time the hey'ati movement (with few exceptions) became firmly rooted in the conservative camp that was later to be referred to as usulgarān (principalist). Thus it came to play an increasingly important role in the power struggle of Iranian politics (interview with author, 2013). Hajj Mansour Arzi was instrumental in this change. He was involved in several controversies due to his explicit criticism of reformist leaders and currents in the politics of the time. He was also associated with the hardliner vigilante group known as Ansar-e Hezbollah (Hizballāh), and he wielded massive influence over the young students of the theological seminars (houzehā) as well as the Revolutionary Home Guard movement known as basijj.

The politicisation of the hey'atha had started already in the early years of Khamene'i's leadership, but it gained its present ascendancy during the 
presidency of the reformist Mohammad Khatami (1997-2005), and mainly after the repression of the student riots in Tehran and Tabriz of 1999. In that period the usulgarāyān groups in Iran felt the need to counteract the liberalisation process that the new president and his many voters wanted to pursue. My interviewees describe the victory of Khatami in the 1997 elections as a shock:

We gave everything we had for Nouri [Nateq Nouri was the opponent of Khatami in the 1997 elections] and some hey'atīha really demonised Khatami. They said he was like Yazid who killed Hoseyn. And then suddenly 20 million people vote for him. It was like "What happened here?" And people would laugh at us because they knew we were defeated.

interview with author, 2013

Khatami's landslide victory made many hey'atīha feel politically and socially isolated in Iranian society since such an overwhelming majority of the people had voted for liberalisation and reform. "Many of us became a bit more cautious after that," another interviewee tells me. "At the same time there was a strong feeling that the revolutionary values were threatened and that this called for a major mobilisation against the reformist tendencies" (interview with author, 2013).

During Khatami's second presidency, the hey'atī movement became instrumental in Mahmoud Ahmadinejad's presidential campaign. Ahmadinejad became mayor of Tehran in 2003 and in this position he allocated resources to the hey'athā and maddāhān in the capital. These groups, as well as maddāhān across the country, would later publicly endorse his candidacy, and some of the most influential ones would even take part in his promotion. Hajj Mansour Arzi himself was one of these. He travelled around the country with Ahmadinejad to promote his candidacy, and he was also criticised for doing this, mainly because of his closeness to the Supreme Leader, who is supposed to take a neutral stance in presidential elections. Another prominent maddāh who supported Ahmadinejad was Hajj Mansour Arzi's former student, Hajj Said Haddadian (interview with author, 2013).

In the years prior to the election of Ahmadinejad in 2005, the hey'ati movement grew on a massive scale. In many small cities, my interviewees from the movement tell me, they had not even had hoseyniehs until this period. Before, hey'atī meetings had taken place in mosques or shrines (imāmzādeha), but now purpose-built hoseyniehs were erected for the first time as a part of the general mobilisation of conservative forces against the reformists (interview with author, 2013). Some of these relatively new small city hoseyniehs would 
later become the gathering places for some of the most radical hey'atī communities. My interviewees remember hey'atī life during this period as a popular movement characterised by increasing enthusiasm and the return of revolutionary spirit. When Ahmadinejad won the elections in 2005, they saw it as the expected outcome of their efforts (interview with author, 2014).

The re-election of Ahmadinejad in June 2009 was the beginning of a turbulent time in Iran. Ahmadinejad's foremost rival, Mir Hoseyn Mousavi, was a close associate of Khatami, with massive support among certain strata of Iranian society. For months before the election, his supporters had gathered in the streets of Tehran and other cities to manifest their support for his candidacy and their disappointment with the hardliner politics of Ahmadinejad. When it was announced that Ahmadinejad had won the election with 63 per cent of the votes, Mousavi and other reformist leaders accused the authorities of having stolen the election, and the reformist rallies in Tehran continued in what was soon to become the most massive public protest since the Revolution, thirty years before.

Many of the hey'atih $\bar{a}$ I have interviewed think that the allegations of cheating are absurd. As they describe it, they had experienced the massive popular support for Ahmadinejad and felt the tailwind of their own movement (interview with author, 2014). For them, the Green movement (jonbesh-e sabz) - as the pro-reformist protestors came to be called-was an expression of decadence and a result of manipulation by the enemies of the Islamic Republic. "It has been proven," one of them told me, "that the whole thing was instigated by American infiltrators" (interview with author, 2014). Of course there most certainly were also people with a hey'atì background among those who demonstrated in the sea of green, but as a movement the hey'atīha $\bar{a}$, or a vast majority of them, were on the side of Ahmadinejad and the Supreme Leader.

During and since Ahmedinejad's presidential terms, the maddāhān and their hey'atha have become increasingly present in Iranian society and public debate. On the one hand the visibility of the maddāhān has increased in the Iranian broadcast media through the growth of social media like YouTube, or the Iranian counterpart, Aparat.com; at the same time, the elaborate individual websites maintained by many maddāhān, with clips of maddāhān performing their eulogies, have become more accessible than ever before. This development has not passed without criticism. On the contrary, many influential thinkers on the reformist side-among them the famous philosopher Abdolkarim Soroush-have openly criticised the role that usulgarān maddāhān have begun to play in Iranian public debate (Soroush 2016). There have also been a number of controversies connected to various maddāhān and their connections with dubious fractions in the political establishment. 
As a religious institution of growing importance, the hey'athäs activities have also been further formalised and professionalised. Measures have been taken to control the hey'athā gatherings and to make sure that the maddāhān style of singing, as well as the ideological and theological content of their poetry, is in line with the doctrines of the clerical establishment. For instance, state-sanctioned education and a special maddāh diploma have been established in order to certify this (Deutsche Welle-Persian 2016).

\section{Madāhān in a Changing Landscape of Islamic Authority}

In Twelver Shīism, the question of the limits and status of religious authority has constituted perhaps the most prominent focus point of the last century's theological and jurisprudential debates. This focus is also reflected in the scholarly research on this branch of Islam, where much energy has been put into the analysis of the changing role of religious authority following the Islamic Revolution.

In the broader field of religious authority studies, a recent shift is the turn away from a one-sided focus on the discursive aspects of authority and a developing interest in material and bodily aspects. Much research emphasises that religious authority cannot be explained if the social and aesthetic framing of authoritative words are ignored. Max Weber's categorisation of authority into charismatic, traditional and legal-rational types-which has dominated the study of religion and authority for so long - has also been challenged by a theoretical movement that emphasises the fluid, relational and narrative aspects of culture, religion and power at large (Krämer and Schmidtke 2010: 2). Furthermore, an increased emphasis on the agency of those subordinated to religious authority can also be distinguished in much research (see, for instance, Mahmood 2005, Hirschkind 2001).

In the following I will connect to these trends by foregrounding the vernacular aspects of Shīite authority that the maddāhān represent in today's Iran and by highlighting the complex and fluid relationships between the aesthetic and charismatic authority that these leaders possess and the bureaucratic authority of the political establishment. I will focus my discussion on three particularly prominent characteristics of the Iranian authority situation: the amalgamation of clerical and charismatic authority, the aesthetics of authority, and the relocation of authority.

The Islamic Revolution led to a situation in which the clergy tightened their grip and control over the maddāhān. At the same time, it entailed a great upsurge for hey'atī culture at large. Indeed, the Islamic Republic was 
from its very beginning upheld by a combination of clerical and charismatic authority. Ruhollah Khomeini himself strikingly combined these two types of authority in his person. As an emotional preacher, he stirred the feelings and frustrations of his followers; as a high-ranking scholar and a marja of Sh'̄ite jurisprudence, he bestowed his legislative authority on these feelings (Mishal and Goldberg 2012: 89). Khomeini maintained the two types of authority by bringing along the above-mentioned maddāh, Kowsari, to his speeches. In this respect Khomeini's practice set the example for an alliance and a division of labour among the two types of religious authority in the velāyat-e faqīh system: at the centre stands the 'a $\mathrm{a}$ lem with his jurisprudential expertise, and at his side, the maddāh who-with his ability to stir the pious emotions of the peoplewould anchor the message in their hearts. Khomeini's example secured a place for the traditional maddāh in the religious and political landscape that was taking shape, and it gave legitimacy to the ritual expressions of the hey'athā.

This alliance has to a large extent remained intact. Today, most maddāhān are fervent supporters of the Supreme Leader, and among them we also find the most outspoken critics of those who challenge his power. A common view in Iran is that the Supreme Leader uses the maddāhän as emissaries who, through their semi-independent position, can express criticism or verbally attack opponents much more bluntly than he himself can.

At the same time, the alliance and the division of labour between establishment clergy and maddāhān has been challenged. Many have criticised the way maddāhān have advanced their position in the Iranian political debate and the crude and impolite language that some of them have used in their critique of reformists. The former chair of the Assembly of Experts (a deliberative body of clerics assigned to supervise the activities of the Supreme Leader), Mohammad Yazdi, recently criticised maddāhān for delivering "banal and false content."

Yazdi, however, has also criticised them for preaching and performing eulogies in a style that is inspired by Western music (Deutsche Welle-Persian 2016). Now these statements are symptomatic of the ambiguous relationship between different types of religious authority in today's Iran. At the same time as the maddāhān function as mouthpieces for the less sanitised messages of the Supreme Leader, they are not an entirely controllable asset. As I have mentioned above, some of the leading clerics of the Islamic Revolution were critical of the maddāhān and their role in society in pre-revolutionary Iran. The major agenda of the Islamic Revolution was to overthrow the monarchic system. Another side of it, however, was to reform Iranian Islamic culture, and one aspect of this was to bring order and control over the many and varying expressions of vernacular religion. From the early days of the Revolution, efforts were made to tighten up the eulogies of the hey'ati meetings and to remove stories 
that were not in line with the official teachings of the new political establishment. The 'álem and philosopher Murtaza Mutahhari wrote a book called The Story of Hoseyn (Hamāse-ye Hoseyni) already before the Revolution for this purpose. In this book, originally a compilation of lectures, he criticised and sought to correct the falsehoods and exaggerations that were conveyed by some maddāhān, and in the immediate post-revolutionary period it was widely used as a basis for criticism of some preachers and for the call for more orthodox content in their poetry and eulogies. Hence already from the beginning of the Islamic Republic the relationship between the maddāhann and the clerical establishment was ambiguous, and this ambiguity prevails today.

Now, Iranian politics is a complicated field in which a number of parallel and often contradictory processes are unfolding at the same time. Two processes that can be discerned over the last decades are the intertwinement of decision-making structures and the centralisation of power. The Islamic Republic's unique constitution is designed with several parallel chains of command: there is the democratic decision-making structure, with the elected parliament and the president; the clerical establishment, with the houzeh seminars and the assembly of experts and the Supreme Leader; the military, with its various regiments; and the Revolutionary Guard, with its many subsections. In the constitution, the Supreme Leader is at the top of all these decisionmaking structures, but in all other respects they are largely independent of one another and separated by Chinese walls. Or at least, that was the original idea.

What has happened over the last decades is that this separation has begun to falter. The Revolutionary Guard's increased involvement in politics (Golkar 2015) is perhaps the foremost example of this. The original idea-declared in the constitution from 1982 and emphasised by Khomeini in his final publication Imam's Final Discourse (199o) — was the sepāh should remain outside politics. Their duty was to execute the decisions decided on by the jurisprudential experts, not to make the decision themselves. This role has now changed. When Mohammad 'Ali Ja'fari was appointed commander of the Revolutionary Guard Corps in 2007, he declared that he considered "dealing with internal threats" to be one of the Guard's most important assignments. He also stated that the Guard should not settle with being solely a military organisation, but that it has to be political and ideological as well (Thurfell 2014). The consequence of this new ambition by the Revolutionary Guards is apparent in large numbers of individuals with a sepāh background who now hold seats in the parliament, the cabinet, as governors, and so forth. The connection between the sepāh, the basīj and the maddāhān has also been strengthened lately. There are today specific branches for maddāhān within the basijj, and several prominent 
maddāhān, such as Mahmoud Karimi or Mehdi Salahshor, are themselves members of the Revolutionary Guard.

Another separation that is dissolving in Iran is the one between clerical and political decision-making structures. Of course, there never was a strict separation between these two. But the idea has at least been that the position of the Supreme Leader - with his jurisprudential expertise and his status as deputy for the Hidden Imam - corresponds to the democratically based authority of the elected president and parliament. A brief glance at the modern history of Iranian politics, however, shows that these structures have not been mutually exclusive. There are many individuals who have built their career in the system on both sides of the fence. 'Ali Khamene'i and Akbar Hashemi Rafsanjani are perhaps the two best-known examples, but the constitutional idea is at least that the two sides should fall back on different forms of authority.

What I seek to pinpoint here concerns the position of the maddāhān and their hey'atīha in relation to these two sides. Traditionally the maddāhān have been on the side of the Islamic jurisprudential authority. After the Revolution, most hey'atīha endorsed the Supreme Leader and the system of velāyat-e faqīh, but they were often critical of elected authorities in the system. "We were so critical of politicians," one former hey'atī told me, "we felt that they didn't promote the feeling of Moharram as much as they should" (interview with author, 2014). The presidential campaign and subsequent election of Mahmoud Ahmadinejad as president of the Islamic Republic in 2005 changed this. As discussed above, many maddāhān were heavily involved in mustering the support for this candidate, and his election marked a change in the relation between the hey'atì subculture and the political establishment. Ahmadinejad, my interviewees tell me, was not perceived as a politician type of person. Instead they felt he was more deeply rooted in the pious Shīite grassroots culture to which they too belonged. Ahmadinejad's two terms as president also entailed that the maddāhän's involvement in politics—and with politicians—increased: for instance, governmental resources were earmarked to fund maddāhān during this period. In this sense, clerical and political authority were brought closer.

This also meant that the connection between the maddāhān and the clergy was strengthened. As mentioned above, the position of the maddāhān has been sanctioned by the clerical establishment since the Revolution. The hey'ati movement has never been an outspokenly anti-clerical movement, and some maddāhān have been clerics, but at the same time the movement is an expression of lay folk religion and there has often been some kind of tension between it and the educated, bookish and clerical Islam of the houzeh seminars. Under Ahmadinejad's presidency, this would change somewhat. All in all, therefore, 
what has befallen during the ten years that has passed since Ahmadinejad was first elected to the presidency is that the different types of authority in the Islamic Republic have become more intertwined. The Islamic jurisprudential authority of the houzeh, the legal authority of the elected bodies, the political and military authority of the sepa $\bar{h}$ and the charismatic folk-religious authority of the maddāhān have become increasingly amalgamated.

The maddāh cleric in Qom with whom I began this chapter exemplifies the amalgamation of the different decision-making structures in the country. He is not a folk-religious maddāh, but a trained clergyman from Qom who in his preaching style has picked up elements from hey'atī culture. In other words, a houzeh scholar with political ambitions and ties to both the sepāh and basij organisations who is also a maddāh and a demagogue on the conservative side of Iranian politics. After we left his gathering, a hey'atī interviewee whom I had accompanied there spoke of him in appreciation:

He is a little bit gentler and smarter than other clergymen. The language that he uses is more understandable for young people. He doesn't speak the way they usually do but uses simpler words. I love his style of talking because he can bring new aspects to what they always repeat. He reads rouzeh gently and finds some artistic aspect that you never saw before, so that you love it little bit deeper.

interview with author, 2014

What he embodies, then, is a consolidation of the various types of authority around the Supreme Leader. This process is unfolding at a time when the usulgarāyān camp of Iranian politics is coming under challenge by the progress of the reformists-including the nuclear deal, the recent electoral successes and the defrosting of international relations-but also at a time when Iran's presence in the many armed conflicts of the region is increasing, the struggle against Daesh in Iraq and Syria being the most prominent example. Both these challenges-domestic and external—are being construed among the hey'atīh $\bar{a}$ as calls for the reawakening and reinvigoration of the "spirit of Moharram" around which their subculture pivots.

On a structural level, the situation can be described as a struggle over the interpretative prerogative to the legacy of the Islamic Republic and the nation of Iran. This struggle is today framed within the polemic between the usulgarān and the esläh talab camps. In the late 199os these camps grew out of a more unified political establishment. The emergence of clear political alternativesin connection with the election of Khatami in 1997-brought with it a diversification of Iranian politics that was much clearer than anything that had 
existed before. Of course, Iranian Islamism has been divided in fractions since before the Revolution. Today's esläh talabān movement are the inheritors of the Iranian Islamic left and the organisation Mojahedin-e enghelāb-e eslāmi, including its founder Behzad Nabavi. Already during the Khomeini period the dividing line between this Islamic left and more hardliner fractions was deep, but Khomeini, most of the time, managed to curb the conflict and uphold an image of unity. Just months before Khomeini's death in 1989, however, the conflict came out in the open in relation to the defrocking of leftist Grand Ayatollah Montazeri, who up until then had been the expected successor of Khomeini. Under the rule of Khamene'i and in the presidency of Rafsanjani, the conflict gradually intensified in order to bloom fully in the Khatami period.

The surfacing of the conflict between esläh talab and usulgarān in Iranian politics can be said to have become the starting-point for the above-mentioned attempt to consolidate the different decision-making structures. The diversification of open political stances hence coincided with the amalgamation of various power structures in and around the usulgarān camp. The maddāhān had an important role to play in this process. In order to understand their role, however, we need to look into the way hey'atī culture is lived and performed in everyday life.

A shift of focus that has occurred in scholarly work on religion lately, and which also can be observed in the study of religious authority, can be found in the increased emphasis on aesthetic, sensorial, bodily and material dimensions (Meyer 2009, 2010; Schulz 2006; Stolow 2005, 2007). Such a focus also turns out to be fruitful when it comes to analysing the changing role of the maddāhān in Iran. I have argued that the new position of the maddāhān in Iran can be construed as a part of the mobilisation and consolidation of the usulgarāyān camp across sections in Iranian society. The maddāhān and their hey'ath $\bar{a}$ are here used as vehicles for political mobilisation, filling the function of anchoring the political and religious messages of the usulgarāyann in the hearts and lives of young people.

As a majority of hey'atīha are young, it is reasonable to approach the hey'atîh $\bar{a}$ as a youth movement and to analyse it analogously with other youth

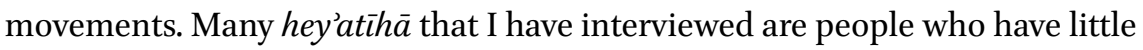
or no religious engagement beyond their hey'atī engagement and who may even be critical of the Islamist system in Iran. Although no statistics are available on this point, this observation gives a hint that the link between a hey'ati lifestyle and the political establishment can at times be rather weak. And when that is the case, hey'ati engagement is more like that of football supporters than other Islamic organisations in the country. Hey'atīha have their own community, their own pop-star-like maddāhān, their own fashionable style of 
clothing, their own shops where they can buy cassettes, posters, pictures of their maddāh and other gear specific to their group, and they have their own places where they socialise. Let me therefore move on to say something about this style-connected side of the movement.

The clothing style of hey'atì groups varies, and not all hey'atīha wear any distinguishable outfit. In certain communities and among the most active members, however, it is common to display a hey'at $\bar{\imath}$ identity through certain attributes. In some places these attributes have some kind of military connotation. Among some groups it has been common to wear army trousers; the kefiye scarf-generally associated with the Palestinian struggle and militaristic Islamist activism - is another common feature, and so is a certain crocheted green cap associated with the Hizballāh leader Emad Moqanieh. Most hey’atī communities, however, have a less militaristic approach. In the community surrounding Seyyed Zaker, in Qom, to take but one example, it is common to wear fashionable and tightly cut black shirts, often with a special type of collar associated with Seyyed Zaker himself. It is also common to wear metal bracelets, rings and other group-specific attributes.

In the post-war period, the hey'atī culture also began to change in terms of ritual style. Up until then it had existed as a ritual extension of the revolutionary movement, which was modern in its connection to Khomeinist ideology, but traditional in its ritual style and musical expression. In the 199os this would change, as the various hey'atī groups became more profiled and the ritual expressions started to change. Many hey'atīha that I have interviewed tend to speak of this stylistic development as a very central aspect of maddāh practice and hey'atī life. They speak of different styles and rhythms, of how maddāhān differ from and are inspired by each other much as a young person belonging to a musical subculture in Europe-be it techno, electronica, R \& B or progressive rock-might be. Here the style of performance is in focus. This does not mean that the wider societal context or the political content is entirely disregarded, but these are not what appear to be in the forefront of the interviewees' minds when asked about the movement.

An important contributor to the stylistic development of the hey'ati expression was a maddāh by the name of Narimane Panahi. He was active in Tehran for a short period during the Ahmadinejad period and his style became influential among hey'atīh $\bar{a}$ across the country. He sang with a hoarse voice and introduced a certain type of backbeat tempo (dam) to the chest-beating sessions. He was also famous for downplaying the poetry aspect of his eulogies. Sometimes, one of my interviewees tell me, he could start a session completely without rouzeh and limit himself to a few lines of poetry, then build the whole session around subtle changes in melody and rhythm, somewhat similar to the 
stylistic manner of much Western techno music (interview with author, 2014). One maddāh I interviewed called Panahi's style a revolution of the whole musical paradigm of hey'atī culture (interview with author, 2013).

Another very important maddāh in furthering the development of this process was, and is still, the above mentioned Mahmoud Karimi. Besides performing traditional eulogies and reading his own poetry, he developed and brought the style of Arzi and Panahi one step further. Like Panahi, he expanded the duration of the repetitive chest-beating, but he also developed a particularly passionate style (sabk-e shur) of doing this. The term shur refers to the passionate form of presentation. The specific hey'atī expression that Karimi developed is characterised by a clear rhythm that is built up and amplified through looping and reverberating effects. He sings his eulogies on top of a beat created by the rhythmic repetition of, for instance, the name of Hoseyn and the thumping of the hey'ati crowd beating their chests. His performances are known for their highly moving and atmospheric feeling, his charismatic persona, and the wholehearted engagement of the crowd. One of his early followers I interviewed tells me that the fascinating thing about him was that he could go on for more than an hour just repeating the name of Hoseyn. Maddāhān like Panahi had reformed the style before him, but no one has yet become as influential as he is. Perhaps this is because of his very professional approach to the task. Karimi, I am told, has a group of assistants around him who help with writing his poetry, and his recordings are professionally produced (interview with author, 2013).

The development of what is sometimes referred to as 'new' hey'ati culture can be said to begin with the stylistic changes made by Karimi in the mid-199os. These new expressions created a new role for the maddāh. More than before, the prayer leaders became performers, the central focus of hey'atī gatherings. People started to choose what meetings to go to based on which maddāh was performing. The most renowned maddāhān today achieve a status similar to that of a pop star: they attract large followings of fans, recordings of their singing are sold and spread on the internet, and their pictures and other objects connected to them are sold as merchandise. For some young hey'atīha the maddāhän are more important as religious authorities than the 'ulamă', and many are very loyal to them (interview with author, 2014).

Following the reforms of Karimi, hey'atī culture can be said to have divided into two styles. The sunnati style is characterised by traditional eulogy readings and is less spectacular in its expression, whereas the shur (sometimes referred to as jadìd or new; interview with author, 2014) hey'atha $\bar{a}$ that follow Karimi's line are more ecstatic and modern in their expression. These latter also tend to attract younger people (interview with author, 2013). One maddāh 
I interviewed told me that Karimi had paved the way for musical reformation also in other hey'athā. "I had lots of problems because I wanted to sing in a new style," he tells me,

I wanted to create this excitement and have some jumping. But it was a catastrophe and there was lots of fighting and they would not accept it. But then we got this [Hajj Mahmoud] Karimi, you know, a very famous maddāh, and he brought a whole new frame of music and a new way of chest-beating (sine zanī) that was more flexible and that became the prototype for a new generation of singers.

interview with author, 2014

Some of the more influential of these maddāhān are Hajj Seyyed Mahdi Mirdamad, Mehdi Salahshor, Hajj Seyyed Haddadian, Hoseyn Sibsorkhi, Abdolreza Helali and Seyyed Javad Zaker. How are we to understand the popularity of these religious leaders? One way is to look at the situation of the young people who are their followers and the historical timing of their popularity. During the Khatami presidential period (1997-2005), two major developments fundamentally changed the everyday situation of young Iranians. One was the liberalisation of society that Khatami's election brought about, at least for some time. One aspect of this was that the ban on Western and popular music became less strict. A second development was the introduction of the internet. This meant that Iranians could now access information-including films, television shows, music and other expressions of global youth culture-more easily than ever before. The election of Ahmadinejad was a setback for those who wished for a continued liberalisation of Iran, but the conservative elements of Iranian society are not blind to the demands of young people and the rise of the hey'atīh $\bar{a}$ coincided with increased efforts to hinder the spread of Western youth culture. This may, therefore, be construed as a more or less conscious attempt to satisfy young people's demands for aesthetic, physical, passionate and youth-oriented activities in a way that also has Islamic sanction. Under Ahmadinejad more resources were allotted to hey'atha, and some other changes that professionalised and brought them closer to the government were also introduced, for instance formal educational programmes for maddāhān. Individual maddāhān have also come to be involved in the political economy of the country in other, sometimes controversial ways. Certain endorsed maddāhān —and through them hey'atı̄ culture at large-have also increasingly been given space in broadcast media.

Dutch anthropologist Ellen van de Bovenkamp has argued that the popularity of Muslim preacher Tariq Ramadan in Morocco can be explained by the fact 
that his charismatic and attractive appearance in a performative way provides young people with a way out of the paralysing dichotomy between the modern and secular on the one hand and the Islamic and traditional on the other that is dominant in their country (Bovenkamp 2015: 226). This analysis is helpful also in understanding the Iranian new hey'atīha $\bar{a}$. They have managed to carve out a religious space that is both youthful and traditional, and also one that succeeds in the delicate task of combining the feel of youthful rebellion with governmental sanction. Despite their passionate commitment to the Shi'ite religion, however, the hey'atīha have also become something of a challenge to the Islamist establishment. Let me now move on to say something about this.

\section{The Renegotiation and Relocation of Authority}

In the following I will connect the hey'atì movement to processes that are developing today within the field of religious authority at large. The maddāhān, and the societal processes that they represent, constitute a challenge to the clerical establishment, not primarily as alternative spokespersons for Islam but in so far as they present a new idea of what role this religion should play in the lives of the faithful. The area that is contested here, then, is not primarily about jurisprudential authority or religio-political ideology but —on a more near-life and everyday note - about what it means to be a Shīite Muslim in Iran today. The maddāhan do not challenge the jurisprudential authority of the 'ulama $\bar{a}^{\prime}$ in any way; on the contrary, many of them are quite eager to stress that they lack formal education in jurisprudential matters. The challenge to jurisprudential authority that they constitute, rather, is not about legal interpretation, but about defining what aspects of a person's life it is that Islam should primarily address. The question of authority is thus in this movement moved from its traditional location among scholars and kings to the arena of aesthetics, physical experience and youth culture. This is also something that is discussed in the Iranian public debate. ${ }^{2}$

This connects to what Gudrun Krämer has described as a proliferation of religious knowledge. The authority structures in the Islamic world have changed, not only as a result of the fragmentation of traditional religious authority associated with the new media situation, but also because of the multiplication of actors who provide religious knowledge. The ' ' ' $l a m \bar{a}^{\prime}$ are still around, but new and, more importantly, additional and alternative types of authority have reached prominence alongside them (Krämer and Schmidtke

2 See for instance, Alef.ir, http://alef.ir/vdcfyydjcw6dxja.igiw.html?401418. Accessed 28/10/2016. 
2010: 12). The hey'atı̃ movement, then, represents a relocation of authority not on the level of scholarly or political position, but by reinterpreting where and in what ways people are letting religion become a part of their lives.

Let me illustrate this point by referring to one of my interviewees. Kalb-e Hoseyn is a man in his late forties. Kalb-e Hoseyn is a pseudonym that he himself chose. It means, literally, Hoseyn's dog, and it reflects the type of piety that is encouraged in this hey'at. Kalb-e Hoseyn belongs to a hey'at in Qom that is dominated by the new hey'atī style, and he thinks of himself as a hey'atī. When I ask him what this identity means to him, he immediately starts talking about his own emotional development and about the performative style of his favourite maddāh. For Kalb-e Hoseyn, hey'atī engagement is all about the feeling. He lived a wild life before he got involved in the movement. There were drugs and a constant seeking of highs. He used to be a bodybuilder and weightlifter and, besides his daytime job as a painter, he used to spend his days working out in the gym and drinking vodka with his friends. "I have been an outsider in many ways," he tells me, "I used to live a crazy life, I tried everything to get a little bit of excitement. But it was a joy that was for myself only, only myself, myself, myself all the time."

One day, Kalb-e Hoseyn tells me, he collapsed. His lifestyle had worn him down and this is when he found relief in the hey'at of a young maddāh in his city. Kalb-e Hoseyn had participated in Shīite devotional rituals in connection to Ashura since his childhood, but what he met now, he tells me, was something new. "The first time I went there I was caught," he says, "I liked the shur style, it made me interested, I felt happiness, you could say that I fell in love." For him the hey'at was something new and a way out of his destructive lifestyle. "My maddāh lit a fire in my heart and I found true happiness," he explains, "This is the path of Imam Hussein" (interview with author, 2014).

Kalb-e Hoseyn was twenty-four years old when he became engaged in the movement. Ten years have passed since that day, and his life has changed for the better. He goes to the hoseynieh as often as he can, and he works as a volunteer with the events they arrange there. He has also married and has a oneyear-old son with whom, he tells me, he likes to listen and cry to recordings of eulogies at home. The hey'atī life has come to dominate his everyday. He prays in the car as he drives between different jobs and he constantly listens to recorded hey'ati meetings. The maddāh who lit the fire in his heart has died, but Kalb visits his grave at least once a week. "This is what makes us different from other Muslims," he tells me, "that we think more about Hoseyn. We don't think about money and material stuff. We are not rich. We are satisfied with this life, and this is the sweetness of Imam Hoseyn, this feeling of satisfaction." 
For Kalb-e Hoseyn his religion is all about the feeling: the feeling that fills him at the hey'ati meetings, the feeling about his maddāh, the feeling of satisfaction in his life. This does not mean that he disrespects the jurisprudential or theological aspects of Islam. There are 'ulam $\bar{a}$ ' who come to the hoseynieh sometimes, he tells me, and he likes them. They give some speech before the rouzeh begins and that is good and okay, "but," he tells me, since he "cannot explain things theologically it is better to go with the feeling. And the feeling is the love for Hoseyn." When I ask about having a marja', he tells me that "if we need a marjac we will pick one who loves Hoseyn." "Some people," he continues with a smile, "have called us käfers because of what we say"-in his hoseynieh, it is said, they once paraphrased the Islamic creed and shouted lä-ilāha-ill-Hoseyn (there is no god but Hoseyn)—but Kalb does not seem so bothered about this. He knows what he has found in the hey'atī lifestyle. It has changed his life and filled him with a feeling of satisfaction and joy that he takes as proof of its authenticity.

\section{5}

\section{Conclusion}

The rise of the hey'atha as a popular youth culture based on aesthetics and emotion constitutes a fundamental challenge to the authority of the 'ulama in virtue of the fact that it neglects their very idea of what authority should be built on. Many hey'atīhā, like Kalb-e Hoseyn, do not care much for fiqh or jurisprudential evidence. They, like most young people, care about emotions. Now as long as they respect and support the authority of the 'ulam $\bar{a}^{3}$, this is in line with Khomeini's idea of a division of labour within the velāyat-e faqīh system, with the jurisprudential expert at the centre and the maddāh at his side, anchoring the message in the hearts of his followers.

But what seems to have happened with the professionalisation of the maddāhān and the development of hey'atī culture in the direction of youth culture over the last decade is that this division of labour has been challenged. Some hey'atīhä-although probably not most of them-see their maddāhān, not as a complement, but as a substitute for the clergy. This, naturally, makes them potentially unreliable for the jurisprudential elite to build their authority on. The above-mentioned maddāh diploma can be understood in this context as an attempt to bring the maddāhän back into line.

These processes are unfolding at a time when Iranian civil society is going through a process of change. Civil society can be defined as "the space between the state and the family, where citizens on a voluntary basis engage with issues 
of societal relevance" (Aarts and Cavatorta 2013: 6). In recent research on Iran, the dynamics of this space have become the subject of increasingly sharp focus. Studying "the dynamics that occur outside formal groups," 'Ali Fathollah-Nejad, for one, has shown that the international sanctions were counterproductive for civil society because they led indirectly to reduced space for democratic activism. In this period, then, the hey'atī movement managed to seize a part of the youth cultural space where the interest in —and the authority of - the Shīite Islamist governmental establishment is waning.

\section{References}

Aarts, P. and F. Cavatorta. 2013. Civil society in Syria and Iran: Activism in Authoritarian Contexts. Boulder and London: Lynne Rienner Publishers.

Amanat, A. 2009. Apocalyptic Islam and Iranian Shicism. New York: I.B. Tauris.

Bovenkamp, van de, E. 2015. "Tariq Ramadan: Fashion or Fiqh? The Powerful Charisma of an Advocate of Islam in the West." Culture and Religion. 16:2, 215-227.

" بإ تائيد وزارت علوم دوره كاردانى "مداحى" ايبجاد شد" . [Educational programme for maddāhān created with the approval of the ministry of science]. At http://www.dw.com/fa-ir/تائيد-وزارت-علوم-دوره-كاردانى-مداحت ايجاد-شد/a-190o8155. Accessed 28/10/2016.

Fischer, M. 1980. Iran: From Religious Dispute to Revolution. Madison: University of Wisconsin Press.

Golkar, S. 2015. Captive Society: The Basij Militia and Social Control in Iran. Washington: Woodrow Wilson Center Press.

Hirschkind, C. 2001. "Civic Virtue and Religious Reason: An Islamic Counterpublic." Cultural Anthropology. 16:1, 3-34.

Khomeini, R. 199o. Imam's Final Discourse: The Text of the Political and Religious Testament of the Leader of the Islamic Revolution and the Founder of the Islamic Republic of Iran, Imam Khomeini. No location: Ministry of Guidance and Islamic culture.

Krämer, G., and Schmidtke, S. 2010. Speaking for Islam: Religious Authorities in Muslim Societies. Leiden and New York: Brill.

Mahmood, S. 2005. Politics of Piety: The Islamic Revival and the Feminist Subject. Princeton: Princeton University Press.

Mazaheri, M.H. 2008. Rasāne-ye shi'eh [The Shi'a Media] Tehran: Islamic Development Organization.

Meyer, B. 2009. Aesthetic Formations: Media, Religion, and the Senses. New York: Palgrave. 
Meyer, B. 2010. "Aesthetics of Persuasion: Global Christianity and Pentecostalism's Sensational Forms." South Atlantic Quarterly. 109:4, 741-763.

Mishal, S. and O. Goldberg. 2014. Understanding Shiite Leadership: The Art of the Middle Ground in Iran and Lebanon. New York: Cambridge University Press.

Mitchell, C. 2011. The Practice of Politics in Safavid Iran: Power, Religion and Rhetoric. New York: I.B. Tauris.

Momen, M. 1985. An Introduction to Shici Islam. New Haven and London:Yale University Press.

Mutahhari, M. N.d. "Ashura-Misrepresentations and Distortions." Trans. Ali Quli Qara'i. Al-Tawhid Islamic Journal. 13:3.

Schulz, D. 2006. "Promises of (Im)Mediate Salvation: Islam, Broadcast Media, and the Remaking of Religious Experience in Mali." American Ethnologist. 33:2, 210-229.

Soroush, A. 2016. "إى مداحان در نعلين روحانيان" [The feet of the maddāhān in the shoes of the 'ulamä']. At http://zeitoons.com/6376. Accessed 28/10/2016.

Stolow, J. 2005. "Religion and/as Media." Theory, Culture, and Society. 22:4, 119-145.

Stolow, J. 2007. "Holy Pleather: Materializing Authority in contemporary Orthodox Jewish Publishing." Material Religion. 3:3, 314-335.

Thurfell, D. 2014. "Khāmene'i utmanad: Shi'itiska alternativ till velāyat-e faqih." In A. Dahlén and C. Jahani eds, Iran: 4000 år av historia, konst, religion, litteratur och språk. Uppsala: Uppsala universitet. 